\title{
Bacterial Lipopolysaccharide-mediated Fetal Death \\ Production of a Newly Recognized Form of Inducible Cyclooxygenase (COX-2) in Murine Decidua in Response to Lipopolysaccharide
}

\author{
Robert M. Silver, ${ }^{*}$ Samuel S. Edwin, ${ }^{*}$ Michael S. Trautman, ${ }^{*}$ Daniel L. Simmons, ${ }^{\$}$ D. Ware Branch, ${ }^{*}$ Donald J. Dudley, ${ }^{*}$ \\ and Murray D. Mitchell* \\ *Departments of Obstetrics and Gynecology and ${ }^{\ddagger}$ Pediatrics, University of Utah School of Medicine, Salt Lake City, Utah 84132; and \\ ${ }^{\S}$ Department of Chemistry, Brigham Young University, Provo, Utah 84602
}

\begin{abstract}
Maternal infection is a cause of spontaneous abortion and preterm labor in humans, but the pathophysiology is unclear. We hypothesized that eicosanoids play an important role in infection-driven pregnancy loss. To investigate this hypothesis, we administered lipopolysaccharide (LPS) to pregnant $\mathrm{C3H} / \mathrm{HeN}$ mice and found that LPS administration caused fetal death in a dose-dependent fashion. Pretreatment with indomethacin significantly decreased the proportion of fetal death from $83 \%$ to $<25 \%$ in mice injected with $10 \mu \mathrm{g}$ of LPS. Also, decidual explants from LPStreated mice produced significantly more inflammatory eicosanoids, including prostaglandins $E_{2}$ and $F_{2 \alpha}$ and thromboxane $B_{2}$, than controls. We investigated the regulatory mechanisms responsible for increased decidual prostanoid production in response to LPS. Western and Northern blots demonstrated that decidual protein and mRNA levels of a recently recognized highly inducible form of cyclooxygenase, COX-2, were substantially increased in mice treated with LPS. Induction of COX-2 was rapid: mRNA was detected 30 min after LPS injection. In contrast, another form of cyclooxygenase, COX-1, was only minimally induced in response to LPS. Our data indicate that LPS induces decidual prostanoid production via increased COX-2 expression. Since LPS-mediated fetal death is markedly diminished by pretreatment with indomethacin, COX-2-mediated eicosanoid production is likely a key pathophysiologic event in LPS-mediated fetal death. (J. Clin. Invest. 1995. 95:725731.) Key words: cyclooxygenase - prostaglandin - pregnancy $\bullet$ fetal death $\cdot$ infection
\end{abstract}

\section{Introduction}

Bacterial infections are a recognized cause of fetal loss in animals and man (1-4). In the case of gram-negative bacterial infections, fetal loss may result in part from the bacterial cell wall component lipopolysaccharide (LPS). LPS has been

Address correspondence to Robert M. Silver, Department of Obstetrics and Gynecology, University of Utah School of Medicine, $50 \mathrm{~N}$. Medical Drive, 2B200, Salt Lake City, UT 84132. Phone: 801-581-7260; FAX: 801-585-5146.

Received for publication 26 April 1994 and in revised form 17 October 1994.

J. Clin. Invest.

(C) The American Society for Clinical Investigation, Inc. 0021-9738/95/02/0725/07 \$2.00

Volume 95, February 1995, 725-731 known to cause fetal death or abortion in animals since 1943 (5) and has been implicated as a cause of preterm labor in humans $(6,7)$. However, the exact mechanism(s) of LPS-induced pregnancy loss remains unclear. LPS induces a marked inflammatory response that is mediated primarily by the activation of macrophages and the release of cytokines and prostanoids (8). The inhibition of prostanoid production with cyclooxygenase $(\mathrm{COX})^{1}$ inhibitors attenuates many of the clinical manifestations of bacterial infection $(9,10)$.

Cyclooxygenase, also known as prostaglandin $\mathrm{H}$ synthase, catalyzes the conversion of arachidonate to prostaglandin $\mathrm{H}-2$ and is a key enzyme in the regulation of prostanoid formation (11). Two related, yet unique isozymes of cyclooxygenase are known to exist. The first isozyme to be identified and cloned from ovine seminal vesicles is now termed COX-1, or prostaglandin $H$ synthase $1(12,13)$. Recently another form of cyclooxygenase, referred to as COX-2 or prostaglandin $\mathrm{H}$ synthase 2, has been described (14-17). Although these enzymes have similar cyclooxygenase and peroxidase activities (18), they are encoded by different genes and have marked regulatory and functional differences. COX-1 is constitutively expressed in many tissues (11). Although small increases in COX-1 can occur in response to hormonal or growth factor stimulation (11, 19), several investigators have failed to show a correlation between the induction of COX-1 mRNA and the induction of prostanoid production in response to mitogens $(20,21)$. In sharp contrast, COX-2 is highly inducible during inflammation (22) or in response to LPS $(23,24)$.

Since prostanoids mediate the signs and symptoms of gramnegative septic shock (25), stimulate myometrium (26), and are capable abortifacients (27), they are likely to be important mediators of LPS-induced pregnancy loss. In these studies we describe the role of prostanoids in LPS-mediated pregnancy loss and show that intrauterine prostanoid production is associated with an increase in the production of COX -2 .

\section{Methods}

Animals. C3H/HeN 6- to 8-wk-old virgin female mice were mated with 8- to 12-wk-old C57Bl/6 males, and the day of coital plugging was taken as day 0 of pregnancy. This allogeneic mating is well characterized and is not abortion prone. Mice were obtained from Sasco Laboratories (Omaha, NE). Animals had free access to food and water and were exposed to a 12-h light/12-h dark cycle. Studies were approved by the University of Utah Institutional Animal Care and Use Committee.

Experimental protocol. Pregnant mice were given a single intraperitoneal injection (1- $\mu \mathrm{l}$ volume) of $10 \mu \mathrm{g}$ of LPS (Escherichia coli serotype 026:B6; L-2880, Sigma Chemical Co., St. Louis, MO) or PBS on

1. Abbreviation used in this paper: $\mathrm{COX}$, cyclooxygenase. 
days 11-13 of gestation. Some animals had subcutaneous time-release pellets of indomethacin (Innovative Research, Toledo, $\mathrm{OH}$ ) placed on day 8 of gestation. These pellets were designed to release indomethacin at either $35 \mu \mathrm{g}$ or $2.5 \mu \mathrm{g} / \mathrm{d}$. Other mice received $14 \mu \mathrm{g} / \mathrm{ml}$ indomethacin in their drinking water, starting on day 8 of gestation. Since mice drink about 3-4 ml of water per day, we estimate that they ingested $\sim 42-$ $56 \mu \mathrm{g}$ of indomethacin per day.

Mice were killed by cervical dislocation $72 \mathrm{~h}$ after the administration of LPS or vehicle, and the status of the fetuses was determined. Gestational sacs were opened, and the fetuses and placentas were evaluated under a $\times 10$ dissecting scope. Live pups were distinguished from fetal deaths (which rarely occur in normal pregnancy) and resorptions (which occur early in pregnancy and are often found in normal murine gestations).

Decidual explants. Explants were established using methods that have been previously described and validated (28). Pregnant mice at days 11-13 of gestation were killed $3 \mathrm{~h}$ after injection with $10 \mu \mathrm{g}$ of LPS or vehicle. After aseptically opening the peritoneal cavity, the pregnant uterus was opened along the antimesenteric border and the gestational sacs and placentas were removed by blunt dissection. Using $\times 10$ magnification, the exposed metrial glands and decidual caps were sharply excised from the uterine wall and cut into fragments of $\sim 1$ $\mathrm{mm}^{3}$. Explants were maintained in $5 \% \mathrm{CO}_{2}$ in air at $37^{\circ} \mathrm{C}$. Culture medium (MEM [ Irvine Scientific, Santa Ana, CA] supplemented with $10 \%$ FCS [Gibco BRL, Grand Island, NY] and antibiotics) was changed every $24 \mathrm{~h}$, and supernatants were taken for determination of prostaglan$\operatorname{din} \mathrm{E}_{2}\left(\mathrm{PGE}_{2}\right)$, prostaglandin $\mathrm{F}_{2 \alpha}\left(\mathrm{PGF}_{2 \alpha}\right)$, and thromboxane $\mathrm{B}_{2}\left(\mathrm{TXB}_{2}\right)$ accumulation. Supernatants were frozen at $-20^{\circ} \mathrm{C}$ until assayed. Replicates of six were used for each experiment.

$P G E_{2}, P G F_{2 \alpha}$ and $T \mathrm{TX}_{2}$ assays. $\mathrm{PGE}_{2}, \mathrm{PGF}_{2 \alpha}$, and $\mathrm{TXB}_{2}$ were measured by sensitive and specific radioimmunoassays using antiserum from Advanced Magnetics (Cambridge, MA) (29). Results were expressed as picograms of $\mathrm{PGE}_{2}, \mathrm{PGF}_{2 \alpha}$, or $\mathrm{TXB}_{2}$ per microgram wet weight of tissue per $24 \mathrm{~h}$.

Western blot analysis. Pregnant mice were killed at serial time points after injection with either $10 \mu \mathrm{g}$ of LPS or vehicle. Deciduae were placed in PBS (0.2 M, ph 7.4) containing $5 \mathrm{mM}$ benzamidine $\mathrm{HCl}, 5$ mM $N$-ethylmaleimide, $1 \mathrm{mM}$ EDTA, $1 \mathrm{mM} \mathrm{PMSF}$, and $5 \mu \mathrm{g} / \mathrm{ml}$ pepstatin and immediately frozen in liquid nitrogen. Frozen tissues were dounced and centrifuged at $2,000 \mathrm{~g}$ at $4^{\circ} \mathrm{C}$ for $15 \mathrm{~min}$ to remove cellular debris. The remaining supernatants were centrifuged at 100,000 $g$ at $4^{\circ} \mathrm{C}$ for $30 \mathrm{~min}$ to purify microsomal proteins. Microsomal proteins were sonicated, and concentrations were determined by the method of Lowry et al. (30).

Microsomes were boiled and separated on $10 \%$ acrylamide gels in Tris glycine electrophoresis buffer. Prestained molecular weight markers (Bio-Rad Laboratories, Hercules, CA), COX-1 protein (purified from ram seminal vesicles; Cayman Chemical Co., Ann Arbor, MI), and purified murine COX-2 protein (Cayman Chemical Co.) were run on each gel. After separation, protein was transblotted to nitrocellulose (Bio-Rad Laboratories). Blots were blocked in a solution containing $3 \%$ non-fat dry milk and incubated in the presence of anti-COX-1 (diluted 1:500) or anti-COX-2 (diluted 1:500) antibodies for $2 \mathrm{~h}$ at room temperature. The anti-COX-1 antibody was generated in rabbits against ram seminal vesicle COX-1; the anti-COX-2 antibody was generated in rabbits against the 18-amino acid $\mathrm{COOH}$ terminus of COX-2 (23). Antibodies were kind gifts of Dan Hwang (Louisiana State University, Baton Rouge, LA). Blots were incubated with biotinylated goat anti-rabbit IgG (diluted 1:3,000; Bio-Rad Laboratories) followed by streptavidin-biotinylated alkaline phosphatase (diluted $1: 3,000$ ). Color development was in alkaline phosphatase color reagents (Bio-Rad Laboratories).

Northern blot analysis. Total cellular RNA was prepared from murine deciduae by the acid guanidinium thiocyanate-phenol-chloroform method of Chomczynski and Sacchi (31). RNA was similarly extracted from cultured NIH3T3 cells (a murine fibroblast cell line; American Type Culture Collection, Rockville, MD) stimulated with $10 \mu \mathrm{g} / \mathrm{ml}$ LPS in RPMI containing 3\% FCS for $6 \mathrm{~h}$, for use as a positive control.
Table I. Murine Fetal Outcome in C3H/HeN Female Mated with C57BL/6 Male Day-12 Pregnant Mice Treated with LPS or PBS

\begin{tabular}{lrcccc}
\hline \multicolumn{1}{c}{ Treatment } & Mice & $\begin{array}{c}\text { Gestional } \\
\text { sacs }\end{array}$ & $\begin{array}{c}\text { Live } \\
\text { fetuses }\end{array}$ & $\begin{array}{c}\text { Fetal } \\
\text { deaths }\end{array}$ & $\begin{array}{c}\text { Fetal } \\
\text { resorptions }\end{array}$ \\
\hline PBS & 12 & 87 & $83(95 \%)$ & 0 & $4(5 \%)$ \\
LPS $(5 \mu \mathrm{g})$ & 8 & 58 & $39(67 \%)$ & $17(29 \%)^{*}$ & $2(3 \%)$ \\
LPS $(7.5 \mu \mathrm{g})$ & 8 & 62 & $28(45 \%)$ & $31(50 \%)^{*}$ & $3(5 \%)$ \\
LPS $(10 \mu \mathrm{g})$ & 12 & 94 & $17(18 \%)$ & $73(78 \%)^{*}$ & $4(4 \%)$
\end{tabular}

* Increasing proportion of fetal death with increasing dose of LPS; $P$ $<0.001$.

Total cellular RNA was separated by electrophoresis in $1 \%$ agaroseformaldehyde gels in the presence of MOPS acetate buffer, $\mathrm{pH} 7.0$ (32). Gels were neutralized in transfer buffer $(0.025 \mathrm{M}$ sodium phosphate, $\mathrm{pH}$ 6.5 ) and blotted onto a synthetic membrane (GeneScreen, New England Nuclear, Boston, MA). RNA was immobilized onto membrane by baking at $80^{\circ} \mathrm{C}$ for $1 \mathrm{~h}$.

Partial cDNA probes for murine COX-1 (1.7 kb) and murine COX$2(1.9 \mathrm{~kb})$ (Oxford Biomedical, Oxford, MI) were radiolabeled with phosphorus-32 using the T-7 polymerase random priming reaction (Stratagene, La Jolla, CA). Blots were hybridized to labeled probes for 16 $\mathrm{h}\left(45^{\circ} \mathrm{C}\right.$ for COX-1 cDNA; $50^{\circ} \mathrm{C}$ for COX-2 cDNA) in $50 \%$ formamide, $2 \%$ dextran sulfate, $5 \times$ Denhardt's solution, $4 \times$ SSC, $0.1 \%$ SDS, 100 $\mu \mathrm{g} / \mathrm{ml}$ salmon sperm DNA, $50 \mu \mathrm{g} / \mathrm{ml}$ yeast tRNA, plus $1 \times 10^{6} \mathrm{cpm} /$ $\mathrm{ml}$ labeled probe. After hybridization, blots were washed and exposed to pre-flashed x-ray film (Hyperfilm, Amersham, Arlington Heights, IL) at $-70^{\circ} \mathrm{C}$. The relative size of $\mathrm{COX}$ transcripts was correlated to the $28 \mathrm{~S}$ and 18S rRNAs from ethidium bromide-stained gels. Blots were stripped and reprobed with a 1.1-kb cDNA encoding a constitutive structural protein, $\mathrm{CHO} \mathrm{B}$, under similar conditions at $45^{\circ} \mathrm{C}$ for $16 \mathrm{~h} \mathrm{(33)}$

Densitometry. Densitometry was performed on an imaging densitometer (model GS-670, Bio-Rad Laboratories). Relative integrated densities were calculated using Molecular Analyst software (Version 1.1, Bio-Rad Laboratories).

Statistical analysis. The proportions of fetal deaths and live pups in treatment groups were compared using chi-square analysis and the Mantel-Haenszel test. Eicosanoid production between groups was compared using the Mann-Whitney U test.

\section{Results}

Fetal outcome for $\mathrm{C} 3 \mathrm{H} / \mathrm{HeN}$ pregnant mice treated with LPS or vehicle is shown in Table I. These data confirm that systemic administration of LPS causes fetal death in a dose-dependent fashion. When mice were killed, gestational sacs containing dead fetuses were hemorrhagic and smaller than those with live pups. Fetal deaths were recognized as containing formed fetuses and placentas. In contrast, resorptions were quite small and had no identifiable fetuses. Gestational sacs and fetuses from a mouse treated with $10 \mu \mathrm{g}$ of LPS and one treated with PBS are shown in Fig. 1. Mice treated with LPS exhibited no obvious maternal side effects, preterm labor, or expulsion of fetuses.

We attempted to block LPS-induced fetal death by pretreatment with indomethacin. As shown in Table II pretreatment with indomethacin significantly reduced the proportion of fetal death following LPS administration from 83 to $25 \% ; P$ $=0.0001$. Since high doses $(35-50 \mu \mathrm{g} / \mathrm{d})$ of indomethacin may have prostaglandin-independent antiinflammatory effects (34), low doses $(2.5 \mu \mathrm{g} / \mathrm{d})$ were also tested. Low doses of 


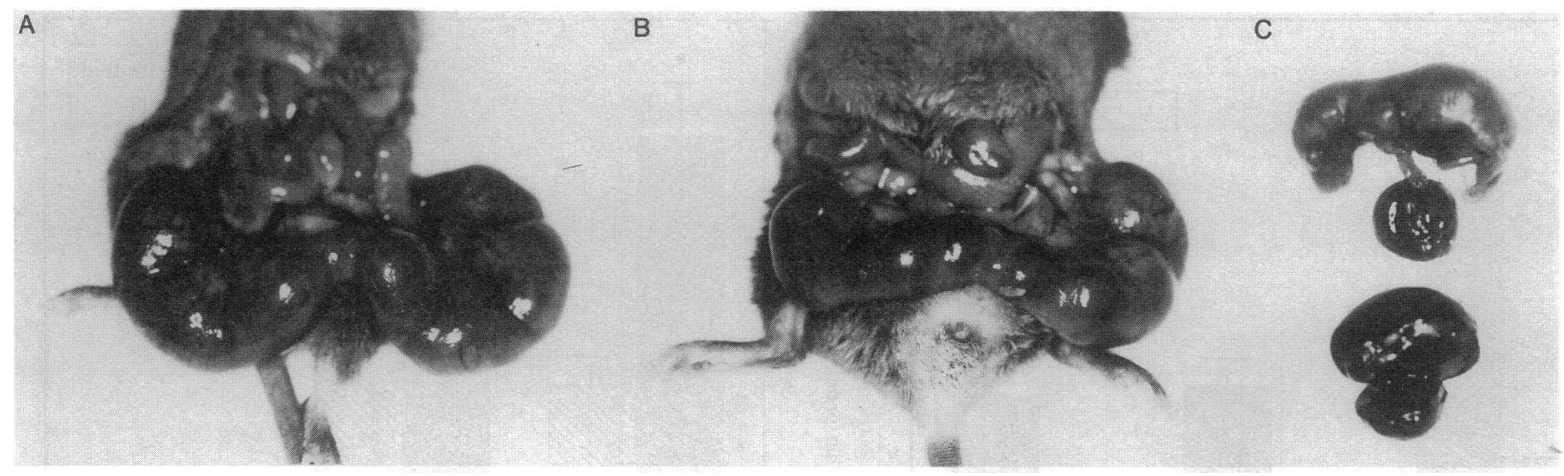

Figure 1. Fetal outcome in mice treated with LPS. Gestational sacs taken from mice injected with PBS $(A)$ or $10 \mu \mathrm{g}$ of LPS $(B)$. (C) a fetus and placenta taken from a mouse injected with PBS (top) and from one injected with $10 \mu \mathrm{g}$ of LPS (bottom).

indomethacin were as effective as higher doses in decreasing the rate of LPS-induced fetal death, suggesting that the effect was a direct consequence of cyclooxygenase inhibition. In vivo absorption of indomethacin was confirmed by using two routes of administration and demonstrating a reduction in uterine $\mathrm{PGE}_{2}$ production in response to LPS in mice treated with indomethacin (see the following discussion).

Next, we used cultures of murine decidual explants to study the effect of in vivo LPS exposure on uterine prostanoid production. Fig. 2 shows the means and standard errors for $\mathrm{PGE}_{2}$ production by decidual explants taken from mice killed $3 \mathrm{~h}$ after injection with $10 \mu \mathrm{g}$ of LPS or vehicle. On each day of explant culture, the mean decidual production of PGE $_{2}$ after LPS injection was significantly greater than that of controls, and the increased mean production of $\mathrm{PGE}_{2}$ persisted through day 3 of culture $(P<0.01)$.

Fig. 3 depicts the means and standard errors for uterine explant $\mathrm{PGE}_{2}$ production in mice pretreated with indomethacin. Indomethacin at both $2.5 \mu \mathrm{g}$ and $35 \mu \mathrm{g} / \mathrm{d}$ effectively blocked uterine $\mathrm{PGE}_{2}$ production in response to LPS administration. These data indicate that treatment with indomethacin inhibited prostaglandin biosynthesis in the decidua.

Since $\mathrm{PGE}_{2}$ has many effects, some of which are proinflammatory and some of which are antiinflammatory, we tested additional decidual explant cultures for the production of $\mathrm{PGF}_{2 \alpha}$ and $\mathrm{TXB}_{2}$ (a stable thromboxane $\mathrm{A}_{2}$ metabolite) as well as $\mathrm{PGE}_{2}$. These eicosanoids are considered to be primarily proinflammatory. The means and standard errors for prostanoid production by decidual explants in the first $24 \mathrm{~h}$ of culture taken from mice killed $3 \mathrm{~h}$ after injection with $10 \mu \mathrm{g}$ of LPS or vehicle are shown in Fig. 4. Results for $\mathrm{PGF}_{2 \alpha}$ and $\mathrm{TXB}_{2}$ were similar to those for $\mathrm{PGE}_{2}$. Explants taken from mice treated with LPS exhibited a twofold and $60 \%$ increase in $\mathrm{PGF}_{2 \alpha}$ and $\mathrm{TXB}_{2}$ production, respectively, compared with controls $(P<0.01)$.

We then sought to investigate the regulatory mechanisms responsible for increased uterine prostanoid production in response to LPS. To test the hypothesis that the induction of COX, specifically the highly inducible isotype COX-2, might increase uterine prostaglandin synthesis, we characterized decidual protein and mRNA production of COX-1 and COX-2 in LPS-treated mice.

Fig. 5 shows a representative Western blot prepared using decidual microsomal proteins taken from animals that were killed at serial time points after injection with $10 \mu \mathrm{g}$ of LPS or vehicle and detected with an antibody against COX-2. COX-2 was present at low levels in decidua from untreated and PBStreated mice. However, COX-2 was increased up to sixfold in deciduae from three animals treated with LPS, as measured by densitometry. This increase in COX-2 protein was most profound 2-4 $\mathrm{h}$ after LPS exposure (four- to sixfold increase), and levels returned to basal amounts $8 \mathrm{~h}$ after LPS administration in all cases. COX-2 was always detected as a single band in murine deciduae. We recognize that others have observed a doublet (23) and speculate that COX-2 may be processed differently in gestational tissues than in other cell types.

Protein ascertained with the antibody against COX-1 was detected at low levels in deciduae taken from untreated animals as well as at all time points after treatment with PBS. In contrast to COX-2, markedly increased levels of decidual COX-1 were not detected after LPS injection. In deciduae from three mice

Table II. Murine Fetal Outcome in C3H/HeN Female Mated with C57B1/6 Male Day-12 Pregnant Mice Treated with LPS, Indomethacin, or Both LPS and Indomethacin

\begin{tabular}{|c|c|c|c|c|c|}
\hline Treatment & Mice & Gestational sacs & Live fetuses & Fetal deaths & Fetal resorptions \\
\hline LPS $(10 \mu \mathrm{g})$ & 8 & 66 & $9(14 \%)$ & $55(83 \%)$ & $2(3 \%)$ \\
\hline Indomethacin $(35 \mu \mathrm{g} / \mathrm{d})^{*}$ & 12 & 93 & $90(97 \%)$ & $1(1 \%)^{\S}$ & $2(2 \%)$ \\
\hline Indomethacin $(35 \mu \mathrm{g} / \mathrm{d})^{*}+$ LPS $(10 \mu \mathrm{g})$ & 12 & 102 & $73(72 \%)$ & $25(25 \%)^{8}$ & $4(4 \%)$ \\
\hline Indomethacin $(2.5 \mu \mathrm{g} / \mathrm{d})^{*}+$ LPS $(10 \mu \mathrm{g})$ & 12 & 98 & $78(80 \%)$ & $18(18 \%)^{8}$ & $2(2 \%)$ \\
\hline Indomethacin (drinking water) ${ }^{\ddagger}+$ LPS $(10 \mu \mathrm{g})$ & 10 & 97 & $72(74 \%)$ & $23(24 \%)^{8}$ & $2(2 \%)$ \\
\hline
\end{tabular}

* Indomethacin administered via subcutaneous time-release pellets. ${ }^{\ddagger}$ Indomethacin administered via drinking water (estimated to be $42-56 \mu \mathrm{g} / \mathrm{d}$ ).

${ }^{\S} \mathrm{A}$ smaller proportion of fetal deaths than mice treated with $10 \mu \mathrm{g}$ of LPS alone; $P=0.0001$. 


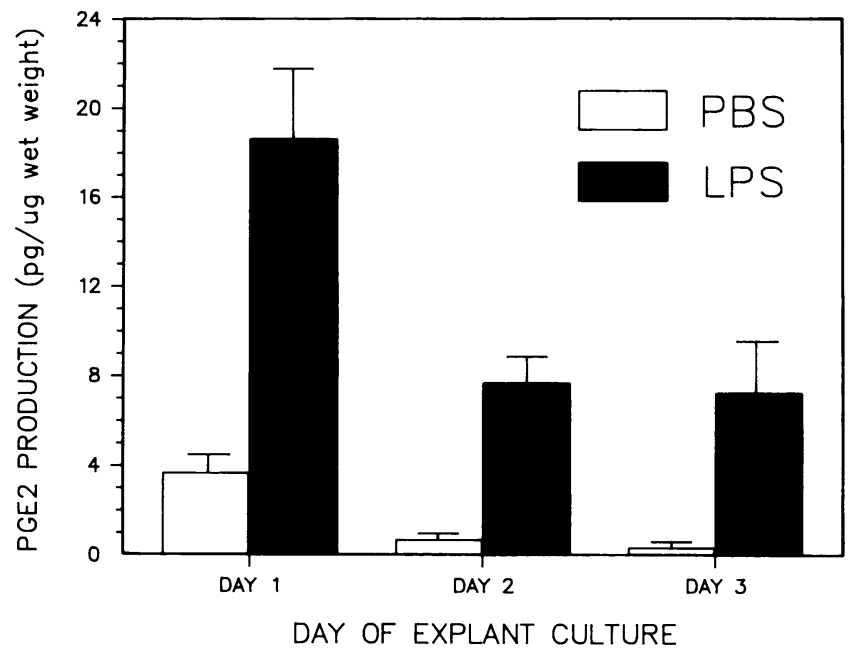

Figure 2. $\mathrm{PGE}_{2}$ production by decidual explants. Production of $\mathrm{PGE}_{2}$ ( mean \pm SEM) over $24 \mathrm{~h}$ by murine decidual explants taken from mice that were killed $3 \mathrm{~h}$ after injection with $10 \mu \mathrm{g}$ of LPS $(N=8)$ or PBS $(N=8)$. Replicates of six were used for each experiment. $\mathrm{PGE}_{2}$ production by explants from LPS-treated mice was greater than that by explants from PBS-treated mice on all $3 \mathrm{~d}(P<0.01$; Mann-Whitney $\mathrm{U}$ test $)$.

treated with LPS, COX-1 levels were unchanged from untreated or PBS-treated mice at 1,6 , and $8 \mathrm{~h}$ after injection. In each animal. COX-1 levels were slightly increased at 2 and $4 \mathrm{~h}$ after LPS administration. However, the increases were modest and averaged $40 \%$. The anti-COX-1 antibody cross-reacted with COX-2, precluding definitive conclusions about COX-1 expression.

A representative Northern blot of decidual RNA hybridized with a partial cDNA for COX-2 is depicted in Fig. 6. COX-2 mRNA was not detected at any time point in deciduae taken from four PBS-injected animals. However, in LPS-treated ani-

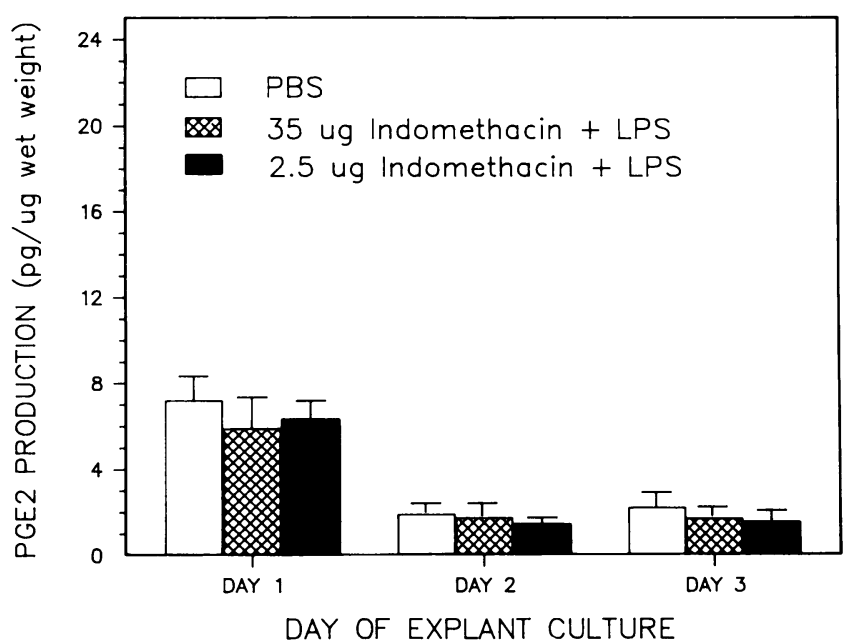

Figure 3. $\mathrm{PGE}_{2}$ production by decidual explants taken from mice pretreated with indomethacin. Production of $\mathrm{PGE}_{2}$ ( mean \pm SEM) over 24 $\mathrm{h}$ by murine decidual explants taken from mice that were sacrificed 3 $\mathrm{h}$ after injection with $10 \mu \mathrm{g}$ of LPS or PBS. Replicates of six were used for each experiment. $\mathrm{PGE}_{2}$ production by explants from LPS-treated mice that were pretreated with indomethacin $(35 \mu \mathrm{g}$ or $2.5 \mu \mathrm{g} / \mathrm{d}$ ) was similar to controls.

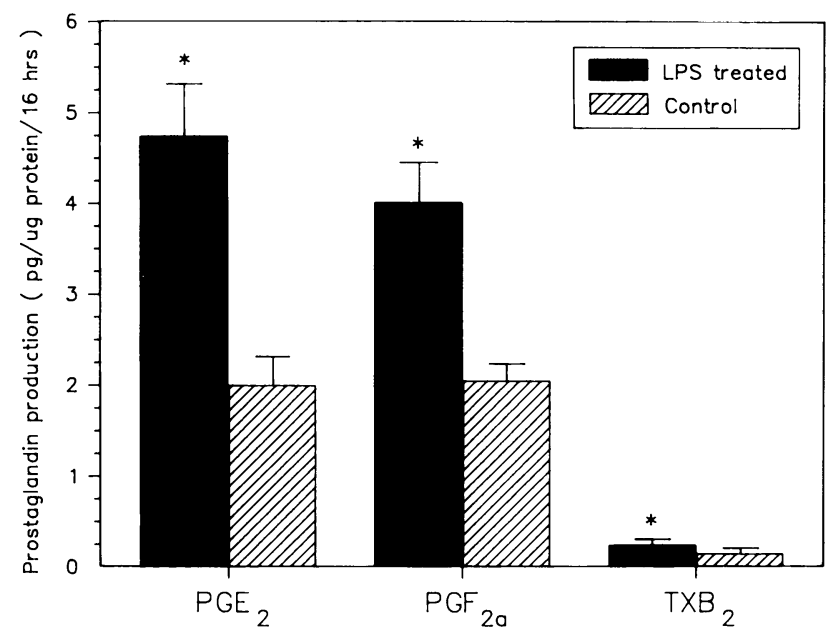

Figure 4. Prostanoid production by decidual explants. Production of $\mathrm{PGE}_{2}, \mathrm{PGF}_{2 \alpha}$, or $\mathrm{TXB}_{2}$ ( mean $\pm \mathrm{SEM}$ ) over $24 \mathrm{~h}$ by murine decidual explants taken from mice that were killed $3 \mathrm{~h}$ after injection with 10 $\mu \mathrm{g}$ of LPS $(N=8)$ or PBS $(N=8)$. Replicates of six were used for each experiment. $\mathrm{PGE}_{2}, \mathrm{PGF}_{2 \alpha}$, and $\mathrm{TXB}_{2}$ production by explants from LPS-treated mice was significantly greater than that by explants from PBS-treated mice ( $* P<0.01$ : Mann-Whitney $\mathrm{U}$ test).

mals, COX-2 mRNA was detected as early as $30 \mathrm{~min}$ after LPS injection; it peaked at $2 \mathrm{~h}$, and was barely detected at $24 \mathrm{~h}$ after injection. COX-2 mRNA was most elevated from 1 to $4 \mathrm{~h}$ after LPS administration in each of four treated animals.

COX-1 mRNA was detected in NIH3T3 cells (as a 3.0-kb
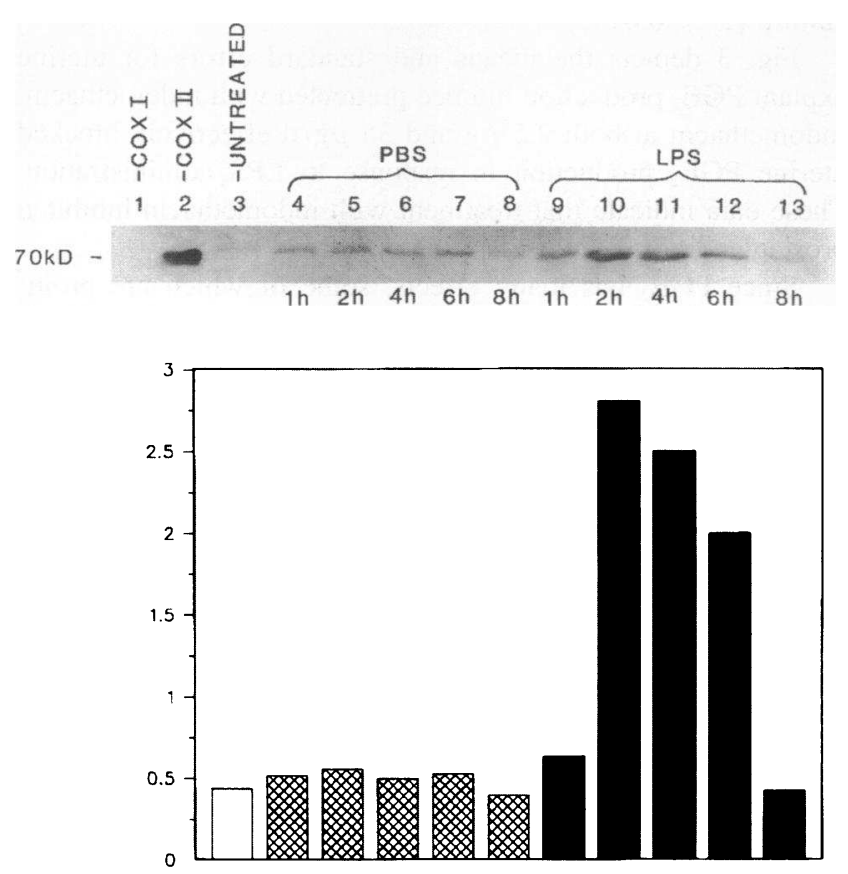

Figure 5. (Top) Western blot of decidual microsomal proteins labeled with an antibody against COX-2. Lane $l, 1 \mu \mathrm{g}$ of COX-1; lane $2,1 \mu \mathrm{g}$ of COX-2; lanes, 3-13, decidual microsomes taken from untreated pregnant mice (lane 3 ) or mice treated with either vehicle (lanes 4-8) or $10 \mu \mathrm{g}$ of LPS (lanes 9-13). Mice were sacrificed at the indicated time points after treatment. (Bottom): Relative densities of bands depicted in pixel density units. 


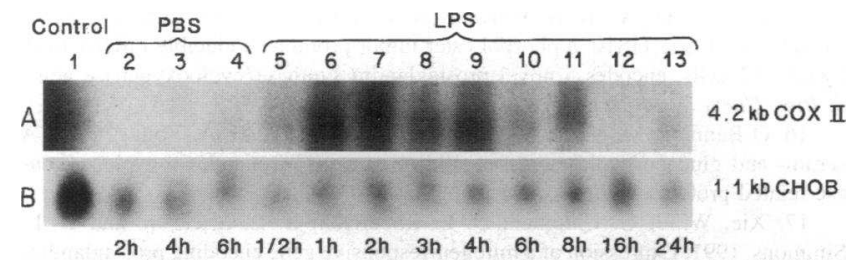

Figure 6. Northern blot of decidual total cellular RNA (30 $\mu \mathrm{g}$ per lane) taken from pregnant mice treated with either $10 \mu \mathrm{g}$ of LPS or vehicle. $(A)$ Hybridization with murine COX-2 cDNA; $(B)$ hybridization with CHO B cDNA. Lane 1, NIH3T3 cells; lanes 2-13, deciduae from mice sacrificed at serial time points after treatment. Lane 2, PBS $2 \mathrm{~h}$; lane 3, PBS $3 \mathrm{~h}$; lane 4, PBS $6 \mathrm{~h}$; lane 5, LPS $0.5 \mathrm{~h}$; lane 6, LPS $1 \mathrm{~h}$; lane 7, LPS $2 \mathrm{~h}$; lane 8, LPS $3 \mathrm{~h}$; lane 9, LPS $4 \mathrm{~h}$; lane 10, LPS $6 \mathrm{~h}$; lane 11 , LPS $8 \mathrm{~h}$; lane 12, LPS $16 \mathrm{~h}$; lane 13, LPS $24 \mathrm{~h}$.

transcript), but was not detected in decidual RNA samples from either PBS- or LPS-treated animals using this technique (data not shown).

\section{Discussion}

Our data show that LPS induces a substantial increase in decidual COX-2 mRNA and protein and suggest that this mechanism plays an important role in LPS-mediated fetal death.

In 1972, Skarnes and Harper first associated LPS-induced abortion with prostaglandins (35). They demonstrated an increase in intrauterine PGF concentrations in pregnant mice treated with LPS and showed that systemic administration of $\mathrm{PGE}_{2}$ and $\mathrm{PGF}_{2 \alpha}$ resulted in murine fetal death (35). In their experiments, pretreatment with $\sim 10 \mu \mathrm{g}(2 \mathrm{mg} / \mathrm{kg})$ of indomethacin blocked fetal expulsion in response to LPS. However, indomethacin did not decrease the rate of fetal death after LPS administration, leading these investigators to conclude that substances other than prostaglandins were responsible for LPSinduced fetal death (35). In contrast, we have demonstrated that murine fetal loss in response to LPS is significantly blocked by indomethacin. Possible reasons for differences between their results and our data include the short duration of indomethacin therapy (2-3 $\mathrm{h}$ prior to LPS injection), the late gestational age of experimentation ( $16 \mathrm{~d}$ ), and the lack of confirmation of prostaglandin blockade in the previous study (35).

The pathophysiology of prostanoid-mediated fetal death is uncertain. $\mathrm{PGE}_{2}$ and other eicosanoids can cause myometrial contractions (26), which could lead to ischemia in the decidua, placenta, and fetus. Other potential mechanisms are decreased perfusion of gestational tissues secondary to increased vascular permeability caused by prostaglandins, or platelet aggregation and vasoconstriction due to thromboxanes (25). LPS may also exert systemic effects on the maternal vasculature that are pathogenic to the fetus. We speculate that prostaglandins may be more important mediators of LPS-induced fetal death than thromboxane, since prostaglandin production in response to LPS was enhanced to a relatively greater degree. Experiments using specific prostanoid inhibitors may help to define further the pathogenic role of each eicosanoid.

It is likely that compounds other than prostanoids contribute to LPS-induced fetal loss, since pretreatment with indomethacin only partially blocked LPS-induced fetal death. Candidates include inflammatory cytokines such as tumor necrosis factor- $\alpha$ and interleukin-1. These potent molecules mediate many of the biological effects of LPS (36), and both cause murine fetal death in a dose-dependent fashion $(37,38)$. Other immune effectors that are induced by LPS and may directly or indirectly harm the fetus are platelet-activating factor, interferon- $\gamma$, and products of lipoxygenase activity (39).

Our data show that in vivo decidual prostanoid production in response to LPS is associated with an increase in the levels of COX-2 mRNA and protein. The induction of COX-2 was rapid, with detectable levels of COX-2 mRNA noted $0.5 \mathrm{~h}$ after LPS administration. Elevations in COX-2 were also short lived: COX-2 protein levels returned to those of untreated animals by $8 \mathrm{~h}$, and COX-2 mRNA was undetectable at $16 \mathrm{~h}$ after exposure to LPS. These data are consistent with several recent reports about the rapid inducibility of COX-2 in a variety of tissues $(15,23,24,40,41)$. COX-1 mRNA was not detected in deciduae from LPS-injected mice, and COX-1 protein levels were stable or only minimally elevated in response to LPS. Since the anti-COX-1 antibody also recognizes COX-2, albeit to a much lesser degree (23), it is unclear whether the slight increase observed in COX-1 protein in LPS-treated mice is due to an actual increase in COX-1 or to cross-reactivity with COX-2. Even if this represents a true elevation of COX-1, such a small induction is unlikely to account for the increase in $\mathrm{PGE}_{2}$ production in uterine decidua and metrial glands after LPS injection.

Since COX-1 is constitutively expressed in many tissues, it has been purported to be a "housekeeping gene" responsible for prostaglandin production and necessary for normal cellular processes (42). Conversely, it has been hypothesized that COX2 is the "inflammatory enzyme" that causes prostaglandin production involved in inflammation and mitogenesis (42). Our data are certainly consistent with such a model.

It is possible that enzymes other than COX-2 are responsible for some of the increased decidual prostanoid production in response to LPS. LPS may induce phospholipases that are important upregulators of prostanoid production. Our studies do not address the issue of whether or not COX-2 enzymatic activity is increased in response to LPS. Thus, we recognize that phospholipases or other enzymes may contribute to LPS-induced prostanoid production in gestational tissues.

It is unclear which uterine cell type is responsible for the elaboration of COX-2 and PGE $_{2}$ in response to LPS. A likely candidate is the uterine macrophage. The murine metrial gland is rich in macrophages (43), and macrophages have been shown to induce COX-2 in response to LPS $(23,24,44)$. Moreover, although both glandular and stromal decidual cells are capable of eicosanoid production (45), studies using flow cytometry have shown decidual macrophages to have the highest rates of $\mathrm{PGF}_{2 \alpha}$ and $\mathrm{PGE}_{2}$ biosynthesis in vitro (46).

The treatment of mice with LPS provides an animal model with which to study the effects of acute LPS-induced inflammatory injury during pregnancy. The pathophysiology of maternal infection is relevant not only to fetal death, but also to other adverse pregnancy outcomes associated with infection, including preterm labor and premature rupture of membranes. Our results indicate that the induction of COX-2 is a key mediator of LPS-induced fetal death and is likely responsible for pathologic events such as preterm labor, premature rupture of membranes, and intrauterine infection, which are known to be associated with elevated prostanoid levels $(47,48)$.

Defining the physiologic roles for each form of COX will provide insight into many processes in reproductive biology. An exciting aspect of such research is the potential for the 
development of selective antagonists for each of these isoenzymes $(42,50)$. Specific COX inhibitors would have promise as therapeutic agents in obstetrics, for example, as a treatment for preterm labor. Although clinically evident infection is a contraindication for tocolysis, there is subclinical, histologic evidence of inflammation or inflammatory changes in gestational tissues in over half of deliveries prior to 32-wk gestation (1). Perhaps because of their antiinflammatory properties as well as their inhibition of prostaglandins, nonsteroidal drugs appear to be effective agents for the treatment of idiopathic preterm labor $(50,51)$. However, their use is severely limited by untoward fetal effects $(52,53)$. It has been suggested that the antiinflammatory actions of cyclooxygenase inhibitors are due to the inhibition of COX-2, whereas unwanted side effects are due to the inhibition of the constitutively expressed COX1 (54). Thus, a selective antagonist for COX-2 merits investigation as a potentially safe and effective treatment for idiopathic preterm labor.

\section{Acknowledgments}

We would like to thank Juliane Andrews for her assistance with this manuscript.

R. M. Silver, MD, is a recipient of the Reproductive Scientist Development Program Award. This work was partially funded by National Institutes of Health grant K12 HD0049.

\section{References}

1. Hillier, S. L., J. Martius, M. J. Krohn, N. Kiviat, K. K. Holmes, and D. A. Eshenbach. 1988. A case control study of chorioamniotic infection and histologic chorioamnionitis in prematurity. N. Engl. J. Med. 319:972-978.

2. McLauchlin, J. 1990. Human listeriosis in Britain. 1967-85. A summary of 722 cases. I. Listeriosis during pregnancy and in the newborn. Epidemiol. Infect. 104:181.

3. Gibbs, R. S., and P. Duff. 1991. Progress in pathogenesis and management of clinical intra-amniotic infection. Am. J. Obstet. Gynecol. 164:1317.

4. McDuffie, R. S., Jr., M. P. Sherman, and R. S. Gibbs. 1992. Amniotic fluid tumor necrosis factor- $\alpha$ and interleukin-1 in a rabbit model of bacterially induced pregnancy loss. Am. J. Obstet. Gynecol. 167:1583-1588.

5. Zahl, P. A., and C. Bjerknes. 1943. Induction of decidua-placental hemorrhage in mice by the endotoxins of certain gram-negative bacteria. Proc. Soc. Exp. Biol. Med. 54:329-332.

6. Romero, R., P. Roslansky, E. Oyarzun, M. Wan, M. Emamian, T. J. Novitsky, M. J. Gould, and J. C. Hobbins. 1988. Labor and infection. II. Bacterial endotoxin in amniotic fluid and its relationship to the onset of preterm labor. Am. J. Obstet. Gynecol. 158:1044-1049.

7. Cox, S. M., P. C. MacDonald, and M. L. Casey. 1988. Assay of bacterial endotoxin (lipopolysaccharide) in human amniotic fluid: potential usefulness in diagnosis and treatment of preterm labor. Am. J. Obstet. Gynecol. 159:99-106.

8. Michalek, S. M., R. N. More, J. R. McGhee, D. L. Rosenstreich, and S. E. Mergenhagen. 1980. The primary role of lymphoreticular cells in the mediation of host responses to bacterial endotoxin. J. Infect. Dis. 141:55-63.

9. Michie, H. R., K. R. Manogue, D. R. Spriggs, A. Rerhaug, S. ODwyer, C. Dinarello, A. Cerami, S. M. Wolff, and D. W. Wilmore. 1988. Detection of circulating tumor necrosis factor after endotoxin administration. N. Engl. J. Med. 318:1481-1486.

10. Spinas, G. A., D. Bloesch, U. Keller, W. Zimmerli, and S. Cammisuli. 1991. Pretreatment with ibuprofen augments circulating tumor necrosis factor- $\alpha$, interleukin-6, and elastase during acute endotoxinemia. J. Clin. Infect. Dis. 163:89-95.

11. DeWitt, D. L. 1991. Prostaglandin endoperoxide synthase: regulation of enzyme expression. Biochem. Biophys. Acta. 1083:121-134.

12. DeWitt, D. L., and W. L. Smith. 1988. Primary structure of prostaglandin G/H synthase from sheep vesicular gland determined from the complementary DNA sequence. Proc. Natl. Acad. Sci. USA 85:1412-1416.

13. Merlie, J. P., D. Fagan, J. Mudd, and P. Needleman. 1988. Isolation and characterization of the complementary DNA for sheep seminal vesicle prostaglandin enderoperoxide synthase (cyclooxygenase). J. Biol. Chem. 263:3550-3553.

14. Simmons, D. L., D. B. Levy, Y. Yannoni, and R. L. Erickson. 1989. Identification of a phorbol ester-repressible v-src-inducible gene. Proc. Natl. Acad. Sci. USA. 86:1178-1182.
15. Kujubu, D. A., B. S. Fletcher, B. C. Varnum, R. W. Lim, and H. R. Herschman. 1991. TIS10, a phorbol ester tumor promoter-inducible mRNA from Swiss $3 \mathrm{~T} 3$ cells, encodes a novel prostaglandin synthase/cyclooxygenase gene. J. Biol. Chem. 266:12866-12872.

16. O'Bannion, M. K., H. B. Sadowski, V. Winn, and D. A. Young. 1991. A serum- and glucocorticoid-regulated 4-kilobase mRNA encodes a cyclooxygenase-related protein. J. Biol. Chem. 266:23261-23267.

17. Xie, W., J. G. Chipman, D. L. Robertson, R. L. Erickson, and D. L. Simmons. 1991. Expression of a mitogen-responsive gene encoding prostaglandinsynthase is regulated by mRNA splicing. Proc. Natl. Acad. Sci. USA. 88:26922696.

18. Fletcher, B. S., D. A. Kujubu, D. M. Perrin, and H. R. Herschman. 1992. J. Biol. Chem. 267:4338-4344.

19. Oshima, T., T. Yoshimoto, S. Yamamoto, M. Kumegawa, C. Yokoyama, and T. Tanabe. 1991. cAMP-dependent induction of fatty acid cyclooxygenase mRNA in mouse osteoblastic cells (MC3T3-E1). J. Biol. Chem. 266:1362113626.

20. Lin, A. H., M. J. Bienkowski, and R. R. Gorman. 1989. Regulation of prostaglandin $\mathrm{H}$ synthase mRNA levels and prostaglandin biosynthesis by platelet derived growth factor. J. Biol. Chem. 264:17379-17383.

21. Wong, W. Y. L., D. L. DeWitt, W. L. Smith, and J. S. Richards. 1989. Rapid induction of prostaglandin endoperoxide synthase in rat preovulatory follicles by leutinizing hormone and cAMP is blocked by inhibitors of transcription and translation. Mol. Endocrinol. 3:1714-1723.

22. Sano, H., T. Hla, J. A. M. Maier, L. J. Crofford, J. P. Case, T. Maciag, and R. L. Wilder. 1992. In vivo expression in synovial tissues of patients with rheumatoid arthritis and osteoarthritis and rats with adjuvant and streptococcal cell wall arthritis. J. Clin. Invest. 89:97-108.

23. Lee, S. H., E. Soyoola, P. Chanmugam, S. Hart, W. Sun, H. Zhong, S. Liou, D. Simmons, and D. Hwang. 1992. Selective expression of mitogen-inducible cyclooxygenase in macrophages stimulated with lipopolysaccharide. J. Biol. Chem. 267:25934-25938.

24. O'Sullivan, M. G., F. H. Chilton, E. M. Huggins, Jr., and C. E. McCall. 1992. Lipopolysaccharide priming of alveolar macrophages for enhanced synthesis of prostanoids involves induction of a novel prostaglandin $\mathrm{H}$ synthase. J. Biol. Chem. 267:14547-14550.

25. Bone, R. C. 1991. The pathogenesis of sepsis. Ann. Int. Med. 1991: 115:457-469.

26. Suzuki, H., and H. Kuriyama. 1975. Effects of prostaglandin $E_{2}$ on the electrical property of the pregnant mouse myometrium. Jap. J. Physiol. 25:201215.

27. Brenner, W. E. 1975. The current status of prostaglandin as abortifacients. Am. J. Obstet. Gynecol. 123:306-328.

28. Dudley, D. J., C. L. Chen, D. W. Branch, E. Hammond, and M. D. Mitchell 1993. A murine model for preterm labor: inflammatory mediators regulate the production of prostaglandin $\mathrm{E}_{2}$ and interleukin- 6 by murine decidua. Biol. Reprod. 48:33-39.

29. Magness, R. R., M. D. Mitchell, and C. R. Rosenfeld. 1990. Uteroplacental production of eicosanoids in ovine pregnancy. Prostaglandins. 39:75-88.

30. Lowry, O. H., N. J. Rosebrough, A. L. Farr, and R. J. Randall. 1951 Protein measurement with the Folin phenol reagent. J. Biol. Chem. 193:265-275.

31. Chomczynski, P., and N. Sacchi. 1987. Single-step method of RNA isolation by acid guanidinium thiocyanate-phenol chloroform extraction. Ann. Biochem. 162:156-159.

32. Maniatis, T., E. F. Fritsch, and J. Sambrook. 1982. Molecular Cloning: A Laboratory Manual. Cold Spring Harbor Laboratory, Cold Spring Harbor, NY. 545 pp.

33. Harpold, M. M., and M. Evans Salditt-Georgrieff. 1979. Production of mRNA in Chinese hamster ovary cells: relationship of the rate of synthesis to the cytoplasmic concentration of nine specific mRNA sequences. Cell. 17:10251035.

34. Abramson, S. B., and G. Weissman. 1989. The mechanisms of action of nonsteroidal antiinflammatory drugs. Arthritis Rheum. 32:1-9.

35. Skarnes, R. C., and J. K. Harper. 1972. Relationship between endotoxininduced abortion and the synthesis of prostaglandin F. Prostaglandins. 1:191203.

36. Cybulsky, M. I., M. K. W. Chan, and Z. Movat. 1988. Biology of disease. Acute inflammation and microthrombosis induced by endotoxin, interleukin-1 and tumor necrosis factor and their implication in gram-negative infection. Lab. Invest. 58:365-378.

37. Silver, R. M., W. S. Lohner, R. A. Daynes, M. D. Mitchell, and D. W. Branch. 1994. Lipopolysaccharide-induced fetal death: the role of tumor-necrosis factor alpha. Biol. Reprod. 50:1108-1112.

38. Silen, M. L., A. Firpo, S. Morgello, S. F. Lowry, and T. Francus. 1989. Interleukin- $1 \alpha$ and tumor necrosis factor- $\alpha$ cause placental injury in the rat. Am. J. Pathol. 135:239-244.

39. Lynn, W. A., and D. T. Golenbock. 1992. Lipopolysaccharide antagonists. Immunol. Today. 13:271-276.

40. Simmons, D. L., W. Xie, J. G. Chipman, and G. E. Evett. 1991. Multiple cyclooxygenases: cloning of a mitogen inducible form. In Prostaglandins, Leuko- 
trienes, Lipoxins, and PAF. J. M. Bailey, editor. Plenum Publishing Corp., New York. 67-78.

41. Mitchell, M. D., S. S. Edwin, S. Lundin-Schiller, R. M. Silver, D. Smotkin, and M. S. Trautman. 1993. Mechanism of interleukin-1 $\beta$ stimulation of human amnion prostaglandin biosynthesis: mediation via a novel inducible cyclooxygenase. Placenta. 14:615-625.

42. DeWitt, D. L., E. A. Meade, and W. L. Smith. 1993. PGH synthase isoenzyme selectivity: the potential for safer nonsteroidal antiinflammatory drugs. Am. J. Med. 95(Suppl. 2A):40-4S.

43. Kearns, M., and P. K. Lala. 1985. Characterization of hematogenous cellular constituents of the murine decidua: a surface marker study. J. Reprod. Immunol. 8:213-234.

44. Masferrer, J. L., K. Seibert, B. Zweifel, and P. Needleman. 1992. Endogenous glucocorticoids regulate an inducible cyclooxygenase enzyme. Proc. Natl. Acad. Sci. USA. 89:3917-3921.

45. Smith, S. K., and R. W. Kelly. 1987. The effect of estradiol-17a and actinomycin D on the release of PGF and PGE from separated cells of human endometrium. Prostaglandins. 34:553-561.

46. Norwitz, E. R., P. M. Starkey, A. Lopez Bernal, and A. C. Turnbull. 1991. Identification by flow cytometry of the prostaglandin producing cell populations of term human decidua. J. Endocrinol. 131:327-334.

47. Romero, R., R. Quintero, M. Emamian, M. Wan, J. C. Hobbins, and M. D.
Mitchell. 1987. Prostaglandin concentrations in amniotic fluid of women with intraamniotic infection and preterm labor. Am. J. Obstet. Gynecol. 157:14611467.

48. Lopez-Bernal, A., D. J. Hansell, T. Y. Khong, J. W. Keeling, and A. C. Turnbull. 1989. Prostaglandin E production by the fetal membranes in unexplained preterm labor and preterm labor associated with chorioamnionitis. Br. J. Obstet. Gynecol. 96:1133-1139.

49. Xie, W., D. L. Robertson, and D. L. Simmons. 1992. Mitogen-inducible prostaglandin G/H synthase: a new target for nonsteroidal antiinflammatory drugs. Drug Dev. Res. 25:249-265.

50. Kurki, T., M. Eronen, R. Lumme, and O. Ylikorkala. 1991. A randomized double-dummy comparison between indomethacin and nylidrin in threatened preterm labor. Obstet. Gynecol. 78:1093-1097.

51. Besinger, R. E., J. R. Niebyl, W. G. Keyes, and T. R. B. Johnson. 1991 Randomized comparative trial of indomethacin for the long-term treatment of preterm labor. Am. J. Obstet. Gynecol. 164:981-988.

52. Moise, K. J., Jr., J. C. Huhta, D. S. Sharif, C. N. Ou, B. Kirshon, N. Wasserstrom, and L. Cano. 1988. Indomethacin in the treatment of premature labor: effects on the fetal ductus arteriosis. N. Engl. J. Med. 319:327-331.

53. Norton, M. E., J. Merrill, B. A. B. Cooper, J. A. Kuller, and R. I. Clyman. 1993. Neonatal complications after the administration of indomethacin for preterm labor. N. Engl. J. Med. 329:1602-1607.

54. Vane, J. 1994. Towards a better aspirin. Nature (Lond.). 367:215-216. 